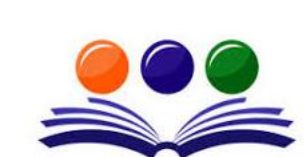

GRAND ACADEMIC PORTAL RESEARCH JOURNALS
GAP iNTERDISCIPLINARITIES A Global Journal of Interdisciplinary Studies

( ISSN - 2581-5628 )

Impact Factor: SJIF - 5.047, IIFS - 4.875

Globally peer-reviewed and open access journal.

\title{
E-COMMERCE: PROMOTING ENTREPRENEURSHIP IN INDIA
}

\author{
Mr Bhavik Barot, Dr Gurudutta Japee \\ Research Scholar, \\ SD School of Commerce, \\ Gujarat University, Ahmedabad \\ Associate Professor, \\ SD School of Commerce, \\ Gujarat University, Ahmedabad
}

\begin{abstract}
E-commerce carries with it its own importance in the corporate world due to the effect of globalisation. Significance of E-commerce further extends in India due to the advent of „Digital India” campaign. Remarkable transformation has been taken place in the field of entrepreneurship by the implementation of effective governance in e-commerce. During last few times amazing renovation have been noticed in the Indian shops and trades. E-commerce has taken the domain of business by storm and fascinated the imagination of whole generation of entrepreneurs, with e-commerce ventures with various business and commercial models. The mercurial development in recent years has already propelled the largest industries among these enterprises crossing the billion-dollar boundary. This article has attempted to highlight the current position of the eCommerce scenario in India and corporate point of view. Simultaneously, it points out the corporate sec strategic drives and challenges, and SCIREA Journal of Agriculture http://www.scirea.org/journal/Agriculture January 13, 2017 Volume 1, Issue 2, December 201644 recommends the techniques which will trigger e-Commerce industries and sustain development.
\end{abstract}

Keywords: business and commercial models, Digital India, E-commerce, entrepreneurs, globalisation.

\section{ECOMMERCE}

E-commerce generally means doing the business transaction by the help of Internet. According to the Organization for Economic Cooperation and Development (OECD), ecommerce is an innovative technique of managing organisation, succeeding it as business happening over systems which use non-proprietary conventions that are recognised through an open standard setting technique such as the Internet. In the other words, E-commerce means the manufacture, circulation, promotion, delivery of products and services by electronic means.

\section{RESEARCH OBJECTIVE}

This article has attempted to highlight the current position of the e-Commerce scenario $\bullet$ in India and corporate point of view. Simultaneously, it points out the corporate sector"s strategic drives and challenges, $\bullet$ and recommends the techniques which will trigger e -commerce industries and sustain development. To study the relevance of governance in Indian e-commerce industry.•

\section{INDIAN E-COMMERCE INDUSTRIES: SWOT ANALYSIS}

3.1 Strengths Less time consuming $\bullet$ Minimize cost of transaction $\bullet 45$ No establishment cost of company• Global target market• Customization in products• Comparison among products• Customer in direct contact• Reduce the cost of operation• More option for segmentation of target market•

3.2 Weaknesses Sometimes high shipping cost• Time consuming for delivery process at certain places• No

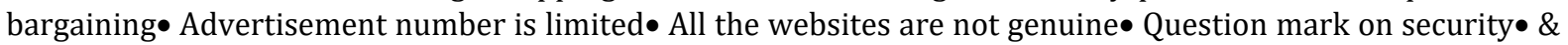
reliability

3.3 Opportunities Latest trends• Updated technologies• Expansion throughout the globe• More scope for growth of the business $\bullet 24 * 7 * 365$ availability $\bullet$ Play above the local competition $\bullet$

3.4 Threats No privacy• High risk• Competitions among competitors 46 Time to time change in the rules• \& regulation of government 


\section{GAP iNTERDISCIPLINARITIES}

A Global Journal of Interdisciplinary Studies

( ISSN - 2581-5628)

FLIPKART Flipkart is one of the leading E-commerce company in India. The company was started in 2007 by Binny\&Sachin Bansal. The industry is registered in Singapore, but has its headquarters in Bangalore, Karnataka, India. Flipkart also comes up with its own product like laptop bags, tablets under the brand name "Digiflip". Morgan Stanley (an American multinational financial services corporation) has lowered the Flipkart valuation from $\$ 15$ billion (May 2015) to $\$ 9.39$ billion (May 2016).

4.1 Strengths: Flipkart Brand Value: Flipkart has proven itself as a popularenterprise in India by• advertisements, online marketing, social websites and different special programs like the "Big billion day" etc... Experience matters a lot: The founders of Flipkart has gained enough prior • experience from "Amazon" regarding how to compete with the competitors in the competitive world. Largest Retailer: Flipkart is the largest Retailer of India in E-commerce Sector.• Minimize the Cost of Operation: Flipkart is minimising its cost of operation by the help of its own payment gateway (Payzippy) and logistic arm (E-kart) Expansion:Flipkart is continuously occupying the new companies like chakpak.com, $\bullet$ weread.com, Mine360, Myntra etc... Wide range of Products:Exclusive rights to promote some goods like MotoG,• MotoX, Xiaomi Mi3 etc...

4.2 Weaknesses:Flipkart Costly: On an average, Flipkart is spending Rs 400/- to acquire a new customer.• Limited Marketing Channel for distribution:Distribution channel of Flipkart is not• able to cover the whole county. 47 Perfect Competition: Customer is always the King in market place in case of perfect• competition.

4.3 Opportunities: Flipkart By targeting certain emerging market, Flipkart can be able to expand its business.• Flipkart can also expands its product categories to increase its customer number $\bullet$ As per the need of the hour new trend is coming in Indian market with respect to „Digital India“ Flipkart can optimize its supply chain to compete with the competitors. $\bullet$ Flipkart can also expand its business out of India•

4.4 Threats: Flipkart Top competition from the local• \& international competitors Government regulation regarding FDI in multi-branding retail•

\section{LOGISTICS}

TRUMP CARD FOR E-COMMERCE IN 2016 E-commerce has perceived an unprecedented growthin the recent year. As per the study of Bank of America Merrill Lynch in 2015, the net value of e-commerce sector in India will be $\$ 220$ billion by 2025 . The concept of E- commerce is just beyond selling the qualitative product. In most of the cases logistic acts as defining factor for e-commerce industries for their customer retention. In the report „Logistics Market in India 2015-2020"Novonous stated that, net worth of the Indian logistic sector at present is $\$ 300$ billion. As per that report, Indian logistic market will grow at a CAGR (compound annual growth rate) of $12.17 \%$ by 2020 .

\section{STRATEGIES OF E-COMMERCE INDUSTRIES IN INDIA IN RECENT YEARS}

Amazon: Amazon accelerated its storage capacity to nearly five million cubic feet by introducing eight new fulfillment centers last year. Amazon claims that it has the largest warehouse capacity \& storage infrastructure in e-commerce sectors with 21 fulfillment centers in India.

Flipkart: Flipkart is associated with its partners for providing alternative delivery channels for customer. Flipkart is also using automation technique for its smooth operation in supply chain management system.

Paytm: Renu Satti, Vice President, Paytm, stated that Paytm is focusing to strengthening its delivery network with the help of local delivery companies. Paytm has introduced two hours delivery model, E-fullfillmentcentre, return processing centres, establishing base for local fulfillment and strengthening local delivery network. Shopclues: According to Vishal Sharma, Vice President, Operations, Shopclues have developed latest technology for faster shipping, real time update on delivery, integrated tracking and information flow.

Snapdeal: Snapdeal triggers its logistic system by introducing the new strategies like „Snapdeal Instant", card on delivery, 90-minute reverse pickups etc...

\section{TRENDS IN INDIAN E-COMMERCE SECTOR}

Recently Retailers Association of India in association with The Boston Consulting Group (BCG) prepared a report. That report provides a bird eye view regarding the upcoming trends in Indian E-commerce sector in next five years.

\section{INDIAN E-COMMERCE WEB TRENDS:}

SOKARTI Sokrati collect information from across $100+$ retailer clients, through 1.4+ million purchases, from over 2+ million transactions regarding Indian e-commerce sector on 2016 The highlight points of Sokarti 
[8] Ben Bajarin. "India Will Be the World's Second Biggest Smartphone Market".TIME.com. Retrieved 4 May 2016.

[9] D. Agrawal, R. P. Agrawal, J. B. Singh and S. P. Tripathi, "E-commerce: True Indian Picture", Journal of Advances in IT, vol. 3, no. 4, (2012), pp. 250-257.

[10] Evolution of e-commerce in India, PwC, 2014.

[11]G. T. Waghmare, "E-commerce; A Business Review and Future Prospects in Indian Business", Internet Marketing in India: Indian Streams Research Journal, vol. 2, no. IV, (2012), pp. 1-4.

[12] https://sokrati.com/blog/current-trends-about-indian-e-commerce-industry/ Retrieved 29th July 2016

[13]J. Bernard and S. Simone, "Bidding on the buying funnel for sponsored search and keyword advertising", Journal of Electronic Commerce Research, vol. 12, no. 1, (2011), pp. 1-18.

[14] Laudon K.C. \& Traver C.G. (2008) E-Commerce Business, Technology, Society, 2nd ed.

[15]Times of india: http://timesofindia.indiatimes.com/tech/tech-news/internet/50-sales-of-ecommercesites-like-Indiatimes-Shopping-Myntra-Jabong-from tierIIIIIcities/articleshow/18460504.cms, (2013)

[16]Z. daniell Wigder and M. Bahl, "Trends in India"s eCommerce Market", Forrester Research, Inc., http://articles.economictimes.indiatimes.com/2013-02- 13/news/37079231_1_mobile-users-net-accessfeature-phones, (2012) August 13. 